\section{OPEN ACCESS}

Manuscript ID:

COM-2021-09023656

Volume: 9

Issue: 2

Month: April

Year: 2021

E-ISSN: 2582-6190

Received: 07.01.2021

Accepted: 21.02.2021

Published: 01.04.2021

Citation:

Parimala, M., and

V. Gayathri. "A Study

on Commerce Students

Attitude towards Online

Classes during Lockdown

Period (With Special

Reference to Madurai

City)." ComFin Research, vol. 9, no. 2, 2021,

pp. 1-8.

DOI:

https://doi.org/10.34293/

commerce.v9i2.3656

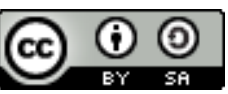

This work is licensed under a Creative Commons Attribution-ShareAlike 4.0 International License

\section{A Study on Commerce Students Attitude towards Online Classes during Lockdown Period (With Special Reference to Madurai City)}

\author{
M. Parimala \\ Associate Professor, Department of Commerce
}

Lady Doak College, Madurai, Tamil Nadu, India

\section{Gayathri}

Assistant Professor, Department of Commerce

Mangayarkarasi College of Arts and Science for Women, Madurai, Tamil Nadu, India

D https://orcid.org/0000-0003-4307-5195

\begin{abstract}
The COVID -19, lockdown period teaches many things to each one of us; all "WH" questions are answered to realize our self like Who we are? How is our life need to be? Which is necessary for life and What are all not important that much. To find the answer to any "WH" questions, critical thinking and knowledge are much important. This lockdown help to unlock our wisdom at the global level. Many of us got a chance to expose talents and skills which is hidden inside of them. Enrolled in online courses, attended webinars which keep each of the active and enthuse to gain more and more knowledge. Arts students get a chance to study basic computer language online courses. Teaching through virtual mode has become the requisite part of educational institutions around the world due to the pandemic crisis of COVID-19. The present study aims to determine the student's attitude towards e-learning, primary data and secondary data were used, primary data has been collected from II and III Year Commerce Students of Lady Doak College and Ambika College of Madurai. By using Convenient Sampling techniques, 120 respondents'datas' are collected with the help of a structured questionnaire. Through e-mail ID, a Google form link was shared to collect the datas'. Tools like Chi-Square, ANOVA, Correlation, t-test and Likert Scaling methods are used to analyze the attitude of the students towards online classes. Even though advantages of e-learning, it would not be meaningful if learners don't adapt to it.
\end{abstract}

Keywords: e-Learning, Students attitude, Online classes, COVID-19, Satisfaction Level, Lockdown Period.

\section{Introduction}

Learning is a continuous process; there is no age limit to learn something new in our life. In the olden days, students go to Gurukulam to learn and equip themselves to be good citizen. Later, so many institutions are started to make the younger citizens be knowledgeable person, Scientists, Doctors, Entrepreneurs etc. The COVID -19 made our routine life itself a tragedy one. All sectors are much affected and freezed. To mold a person as a perfect citizen with social responsibility, education plays a major role. Learning can be the main core not only to the students alone but to the faculties also. Any common changes at a global level may have its impact in any part of the education sector, that this COVID -19 also has its footpath in the education sector too. To stop the spreading of the virus at the global level, educational institutions are forced to shut down, to control the spreading of the virus; because of such reason, virtual platform mode is selected to teach during this lockdown period. 
Thus it paves the way towards e-learning. An education institution was in dilemma to conduct the end semesters for the year 2019 and start the next academic year of II and III year students. Issue of mark sheets to the passed out students, Admission for the fresher's those who completed the Higher Secondary Examination. As per the Government order, all Educational institutions are completed 2019-2020 year and started the next academic year of 2020-21 and now end with ODD semesters with the examination. Students are much affected while comparing with anybody else because of this COVID-19; reason is education determines each of them. In this article, an attempt was made to analysis the Commerce Students Attitude towards Online Classes during lockdown period with Special reference to Madurai City". Learning through virtual mode becomes a part of the education sector, in which the students and faculties are connected comfortably. The use of a desktop, laptop, or smartphones and the internet forms a major component of this learning methodology. So e-learning becomes better for all types of sectors, particularly in the educational sector during the lockdown period.

\section{Statement of the Problem}

Teaching the students on campus changed and shifted to a new environment through virtual mode, which is new to the faculties and the students during this lockdown period. Faculties are informed to handle the classes through Google meeting link, ZOOM, or MS-TEAM. Not only teaching, evaluation with essay questions, Quizes, assignments also needs to be complete. With the backdrop, the present study aims to identify the attitudes of commerce students towards online classes.

\section{Scope of the Study}

Educational institutions are now in a new teaching and learning process with evaluation, which can be new challenges for them. During this COIVD-19 how the institutions performing in a better way for the betterment of students and how students are continuing their learning process through e-learning which can be an adventure for both students and faculties.

\section{Objectives of the Study}

- To Study the Attitude of students towards online classes.

- To Analyze the satisfaction level of students during online classes.

- To Know about factors affecting online classes.

- To Identify the health issues because of online classes.

\section{Review of Literature}

Neelam Dhamija (2016) "A Study on UG students' attitude towards the academic utilization of E-learning". An attitude scale was developed and the study was carried out on 300 students belonging to arts, commerce and science streams. Differences in attitude between different stream students were observed. The findings revealed that overall it was an affirmative approach towards E-learning among most of the students. There were no differences in attitude between arts and commerce students as well as arts and science students. Also, no differences reported between commerce and science students. Though, significant difference was reported among students concerning gender \& rural \& urban residence.

\section{Methodology of the Study \\ Research Design}

Descriptive and Analytical Research Design.

\section{Determination of Sample Size}

Sample Size: 120 (91 Respondents from Lady Doak College, 29 Respondents from Ambiga College Madurai)

Sampling Technique: Convenient Sampling Technique

\section{Sources of Data}

Primary Source: Structured Questionnaire was used to collect the data. Simple Percentage Method, Weighted Average Method, Garrett Ranking Method was adopted to measure the responses.

Method of Data Collection: Google form

\section{Framework of Analysis}

Inferential Statistics: t-Test, ANOVA, ChiSquare and Correlation were adopted to measure the responses. 


\section{Hypothesis}

\begin{tabular}{|c|c|c|c|}
\hline $\begin{array}{l}\text { S. } \\
\text { No }\end{array}$ & $\begin{array}{l}\mathrm{Ho} / \\
\mathrm{H} 1\end{array}$ & Descriptions & $\begin{array}{c}\text { Testing } \\
\text { Methods }\end{array}$ \\
\hline \multirow[t]{2}{*}{1} & H0 & $\begin{array}{l}\text { There is no significant } \\
\text { relationship between Health } \\
\text { issues and duration of } \\
\text { conducting online classes to } \\
\text { the students. }\end{array}$ & \multirow{2}{*}{$\begin{array}{l}\text { Chi- } \\
\text { Square } \\
\text { Test }\end{array}$} \\
\hline & H1 & $\begin{array}{l}\text { There is significant relationship } \\
\text { between Health issues and } \\
\text { duration of conducting online } \\
\text { classes to the students }\end{array}$ & \\
\hline \multirow{2}{*}{2} & H0 & $\begin{array}{l}\text { There is no significant } \\
\text { relationship between usage } \\
\text { of data and platform using in } \\
\text { online classes. }\end{array}$ & \multirow{2}{*}{ t-test } \\
\hline & H1 & $\begin{array}{l}\text { There is significant relationship } \\
\text { between usage of data and } \\
\text { platform using in online } \\
\text { classes }\end{array}$ & \\
\hline \multirow{2}{*}{3} & H0 & $\begin{array}{l}\text { There is no significant } \\
\text { relationship between Teaching } \\
\text { methods and Satisfaction level } \\
\text { of students in online classes. }\end{array}$ & \multirow{2}{*}{ ANVOA } \\
\hline & H1 & $\begin{array}{l}\text { There is significant relationship } \\
\text { between Teaching methods and } \\
\text { Satisfaction level of students in } \\
\text { online classes. }\end{array}$ & \\
\hline
\end{tabular}

\section{Limitations of the Study}

- The study is based on the attitudes of Commerce Students alone and the factors given by them are subjective.

- The study covers only two educational institutions in Madurai city so that it may vary with other colleges within or outside of Madurai city.

- Attitudes of students can be changed at any time, so the same respondents' responses may vary in the future.

\section{Analysis and Interpretation}

\begin{tabular}{|c|c|c|}
\hline $\begin{array}{l}\text { Profile of the } \\
\text { Respondents }\end{array}$ & Frequency & Percent \\
\hline \multicolumn{3}{|c|}{ Age } \\
\hline $18-20$ & 118 & 98.3 \\
\hline $21-22$ & 2 & 1.7 \\
\hline Total & 120 & 100 \\
\hline
\end{tabular}

\begin{tabular}{|c|c|c|}
\hline \multicolumn{3}{|c|}{ Number of Members in Family } \\
\hline Two & 1 & 0.8 \\
\hline Three & 17 & 14.2 \\
\hline Four & 80 & 66.7 \\
\hline More than Six & 22 & 18.3 \\
\hline Total & 120 & 100 \\
\hline \multicolumn{3}{|c|}{ Have Siblings } \\
\hline No & 14 & 11.7 \\
\hline Yes & 106 & 88.3 \\
\hline Total & 120 & 100 \\
\hline \multicolumn{3}{|c|}{ Number of Siblings Studying } \\
\hline One & 61 & 50.8 \\
\hline Two & 12 & 10.0 \\
\hline Three & 2 & 1.7 \\
\hline Four & 3 & 2.5 \\
\hline Not Studying & 28 & 23.3 \\
\hline Total & 106 & 88.3 \\
\hline \multicolumn{3}{|c|}{ Educational Qualification of Siblings } \\
\hline Primary & 2 & 1.6 \\
\hline Secondary & 10 & 8.3 \\
\hline Higher Secondary & 26 & 21.7 \\
\hline Under Graduate & 29 & 24.2 \\
\hline Post Graduate & 11 & 9.2 \\
\hline Not Studying & 28 & 23.3 \\
\hline Total & 106 & 88.3 \\
\hline \multicolumn{3}{|c|}{ Number of Siblings Attend Online Classes } \\
\hline No & 28 & 23.3 \\
\hline Yes & 78 & 65 \\
\hline Total & 106 & 88.3 \\
\hline \multicolumn{3}{|c|}{ Year of Studying } \\
\hline II Year & 42 & 35.0 \\
\hline III Year & 78 & 65.0 \\
\hline Total & 120 & 100.0 \\
\hline
\end{tabular}

\begin{tabular}{|l|c|c|}
\hline $\begin{array}{c}\text { Academic Details } \\
\text { of the Respondents }\end{array}$ & Frequency & Percent \\
\hline $\begin{array}{l}\text { Name of the Institution in which the Respondents } \\
\text { are Studying }\end{array}$ \\
\hline $\begin{array}{l}\text { Ambiga College, } \\
\text { Madurai }\end{array}$ & 29 & 24.2 \\
\hline $\begin{array}{l}\text { Lady Doak College, } \\
\text { Madurai }\end{array}$ & 91 & 75.8 \\
\hline Total & 120 & 100.0 \\
\hline
\end{tabular}




\begin{tabular}{|c|c|c|c|c|c|}
\hline Details - Online Classes & Frequency & Percent & \multicolumn{3}{|c|}{ Number of Hours in a Day } \\
\hline \multicolumn{3}{|c|}{ Online Classes Started on } & One Hour & 28 & 23.3 \\
\hline June 2020 & 29 & 21.7 & Two Hours & 2 & 1.7 \\
\hline August 2020 & 91 & 73.3 & Three Hours & 82 & 68.3 \\
\hline Total & 120 & 100 & More Than 3 Hours & 8 & 6.7 \\
\hline \multicolumn{3}{|c|}{ Have Own Gadget to Attend the Online Classes } & Total & 120 & 100.0 \\
\hline No & 21 & 17.5 & \multicolumn{3}{|c|}{ Break Time between the Classes } \\
\hline Yes & 99 & 82.5 & No & 57 & 47.5 \\
\hline Total & 120 & 100.0 & Yes & 63 & 52.5 \\
\hline \multicolumn{3}{|c|}{ Type of Gadgets Available in Home } & Total & 120 & 100.0 \\
\hline Laptop & 3 & 2.5 & \multicolumn{3}{|c|}{ Duration of Break Time } \\
\hline Smart Phone & 77 & 64.2 & 10 Minutes & 49 & 40.8 \\
\hline Smart Phone and Laptop & 28 & 23.3 & 5 Minutes & 14 & 11.7 \\
\hline \multirow{2}{*}{$\begin{array}{l}\text { Smart Phone, Laptop, } \\
\text { Personal Computer }\end{array}$} & \multirow{2}{*}{5} & \multirow{2}{*}{4.2} & Total & 120 & 100.0 \\
\hline & & & \multicolumn{3}{|c|}{ Mode of Platform } \\
\hline \multirow{2}{*}{$\begin{array}{l}\text { Smart Phone, Personal } \\
\text { Computer }\end{array}$} & \multirow{2}{*}{3} & \multirow{2}{*}{2.5} & Google Class Meet & 91 & 75.8 \\
\hline & & & Zoom & 29 & 24.2 \\
\hline Smart Phone, Tablet & 1 & 0.8 & Total & 120 & 100.0 \\
\hline \multirow{2}{*}{$\begin{array}{l}\text { Smart Phone, Tablet, } \\
\text { Laptop, Personal Computer }\end{array}$} & \multirow{2}{*}{2} & \multirow{2}{*}{1.7} & \multicolumn{3}{|c|}{ Material used to Deliver the Content } \\
\hline & & & PPT & 56 & 46.6 \\
\hline Tablet, Laptop & 1 & 0.8 & Word Documents & 38 & 31.6 \\
\hline Total & 120 & 100.0 & Videos & 18 & 15 \\
\hline \multicolumn{3}{|c|}{ Type of Gadget Using for Online Classes } & Other & 8 & 6.6 \\
\hline Laptop & 8 & 6.7 & Total & 120 & 100.0 \\
\hline Laptop, Tablet & 1 & 0.8 & & & \\
\hline Smart Phone & 98 & 81.7 & \multirow{2}{*}{$\begin{array}{l}\text { Smart Phone and Data } \\
\text { Connection }\end{array}$} & \multirow{2}{*}{ Frequency } & \multirow{2}{*}{ Percent } \\
\hline Smart Phone, Laptop & 13 & 10.8 & & & \\
\hline Total & 120 & 100.0 & \multicolumn{3}{|c|}{ Sim Card for Data Connection } \\
\hline \multirow{2}{*}{\multicolumn{3}{|c|}{$\begin{array}{l}\text { Number of Subjects Studying through Online } \\
\text { Classes }\end{array}$}} & Act-Fibernet & 1 & 0.8 \\
\hline & & & Airtel & 50 & 41.7 \\
\hline Four & 10 & 8.3 & Idea & 7 & 5.8 \\
\hline Five & 58 & 48.3 & Jio & 51 & 42.5 \\
\hline Six & 40 & 33.3 & Vodafone & 10 & 8.3 \\
\hline More than Six & 12 & 10.0 & WIFI & 1 & 0.8 \\
\hline Total & 120 & 100.0 & Total & 120 & 100.0 \\
\hline \multicolumn{3}{|c|}{ Prior Information to the Online Classes } & \multicolumn{3}{|c|}{ Offer Availed during the Recharge } \\
\hline No & - & -- & No & 93 & 77.5 \\
\hline Yes & 120 & 100.0 & Yes & 27 & 22.5 \\
\hline Total & 120 & 100.0 & Total & 120 & 100.0 \\
\hline Schedule for Onlir & Classes Giv & & Amount Spen & o Recharge & \\
\hline No & $\frac{-}{120}$ & $\frac{-}{1000}$ & Above Rs.600 & 10 & 8.3 \\
\hline Yes & $\frac{120}{120}$ & $\frac{100.0}{1000}$ & Less Than Rs.100 & 12 & 10.0 \\
\hline Total & 120 & & Rs. $200-$ Rs. 400 & 33 & 27.5 \\
\hline
\end{tabular}




\begin{tabular}{|c|c|c|}
\hline Rs.400 - Rs. 600 & 17 & 14.2 \\
\hline Total & 120 & 100.0 \\
\hline \multicolumn{3}{|c|}{ Using of Mobile Data } \\
\hline One Month Data Pack & 1 & 0.8 \\
\hline Hotspot & 2 & 1.7 \\
\hline $\begin{array}{l}\text { Integrated Service Digital } \\
\text { Network (ISDN) }\end{array}$ & 1 & 0.8 \\
\hline Through Wireless Modem & 1 & 0.8 \\
\hline Through My Own Network & 102 & 85.0 \\
\hline Through WIFI Connection & 13 & 10.8 \\
\hline Total & 120 & 100 \\
\hline \multicolumn{3}{|c|}{$\begin{array}{l}\text { Health Problems while using Smart Phones and } \\
\text { Computers }\end{array}$} \\
\hline No & 37 & 30.8 \\
\hline Yes & 83 & 69.2 \\
\hline Total & 120 & 100.0 \\
\hline
\end{tabular}

\begin{tabular}{|c|c|c|}
\hline \multicolumn{3}{|c|}{ Types of Health Problem } \\
\hline Anxiety and Depression & 14 & 11.7 \\
\hline Head Ache & 20 & 17 \\
\hline Eyestrain And Eye Pain & 40 & 33 \\
\hline Neck Pain, Back Pain & 4 & 3.3 \\
\hline Other Problems & 5 & 4.1 \\
\hline Total & 83 & 69.2 \\
\hline \multicolumn{3}{|c|}{ Preference of Learning Mode } \\
\hline Physical Class Room & 104 & 86.7 \\
\hline Virtual Mode & 16 & 13.3 \\
\hline Total & 120 & 100.0 \\
\hline
\end{tabular}

Online Class Gives Relief and Relaxation from the Pandemic Time

\begin{tabular}{|c|c|c|}
\hline No & 74 & 61.7 \\
\hline Yes & 46 & 38.3 \\
\hline Total & 120 & 100.0 \\
\hline
\end{tabular}

\begin{tabular}{|c|c|c|c|c|}
\hline \multirow{2}{*}{ Opinion } & \multicolumn{2}{|c|}{ Frequency } & \multicolumn{2}{|c|}{ Percent } \\
\hline & No & Yes & No & Yes \\
\hline $\begin{array}{l}\text { Are You Already Aware of the Platform Which Now You are Using for the Online } \\
\text { Class? }\end{array}$ & 36 & 84 & 30.0 & 70.0 \\
\hline $\begin{array}{l}\text { Do You Find any Difficulty to Use the Tools or to Handle the Platform Using for the } \\
\text { Online Class? }\end{array}$ & 64 & 56 & 53.3 & 46.7 \\
\hline Is There any Activity/Assessment is Conduct during the Online Class? & 10 & 110 & 8.3 & 91.7 \\
\hline Whether the Online Class is Interactive & 36 & 84 & 30.0 & 70.0 \\
\hline $\begin{array}{l}\text { Whether Your Faculty Well Prepared for the Online Class and Using the Technology } \\
\text { in Best Way? }\end{array}$ & 13 & 107 & 10.8 & 89.2 \\
\hline $\begin{array}{l}\text { Do You Feel Those Faculties are not Able to Handle and Monitor the Class Effective } \\
\text { in Online? }\end{array}$ & 95 & 25 & 79.2 & 20.8 \\
\hline Total & \multicolumn{2}{|c|}{120} & \multicolumn{2}{|c|}{100} \\
\hline
\end{tabular}

Source: Primary data

\section{Likert Scaling}

Satisfaction Level of the Respondents Regarding Online Classes

\begin{tabular}{|c|c|c|c|c|c|}
\hline Consider & $\begin{array}{c}\text { Highly Satisfied } \\
\text { (HS) }\end{array}$ & $\begin{array}{c}\text { Satisfied } \\
\text { (S) }\end{array}$ & $\begin{array}{c}\text { Dissatisfied } \\
\text { (DS) }\end{array}$ & $\begin{array}{c}\text { Neither Satisfied Nor } \\
\text { Dissatisfied (ND) }\end{array}$ & $\begin{array}{c}\text { Highly Dissatisfied } \\
\text { (HDS) }\end{array}$ \\
\hline Value & 5 & 4 & 3 & 2 & 1 \\
\hline
\end{tabular}

\begin{tabular}{|l|c|c|c|c|c|c|c|}
\hline \multicolumn{1}{|c|}{ Factors } & HS & S & DS & ND & HDS & Mean Score & Rank \\
\hline I satisfied with the Security Issues & 12 & 30 & 8 & 54 & 16 & 3.117 & X \\
\hline I satisfied with video and audio clarity during the class & 26 & 39 & 23 & 28 & 4 & 3.5 & VI \\
\hline Interaction between student and teachers is weak & 49 & 28 & 20 & 2 & 21 & 3.533 & VIII \\
\hline Delivery of the content are understandable & 32 & 46 & 5 & 31 & 6 & 3.775 & III \\
\hline Problem papers are easy to understand & 20 & 37 & 3 & 53 & 7 & 3.5 & VI \\
\hline I don't have any network problems during online classes & 18 & 37 & 15 & 47 & 3 & 3.433 & IX \\
\hline
\end{tabular}




\begin{tabular}{|l|c|c|c|c|c|c|c|}
\hline $\begin{array}{l}\text { My family environment is suitable to learn and } \\
\text { financially affordable }\end{array}$ & 26 & 61 & 12 & 16 & 5 & 3.758 & IV \\
\hline Usage of teaching aid & 31 & 57 & 1 & 29 & 2 & 3.95 & I \\
\hline I satisfied with assessments and activities of the courses & 21 & 69 & 10 & 8 & 12 & 3.642 & V \\
\hline Time management is effective in online classes & 45 & 38 & 9 & 23 & 5 & 3.908 & II \\
\hline
\end{tabular}

Source: Computed data

From the table, it shows the satisfaction level of students in each statement, in which it was found that most of the students were satisfied with teaching aid used in online classes no problem behind the usage of teaching aids, so it has a high mean score of 3.95 and it was ranked as first. Also, many of the students were satisfied with the time management in online classes, so it has mean score of 3.908 and it was ranked second. Video and audio clarity and understanding of problem papers were got the same rank as sixth. Most of the students were not satisfied with the security issues because they don't have

proper security protection and it was ranked as last because the students were are not satisfy with the security issues when compared to other apps.

\section{Chi-Square Test}

H0: There is no significant relationship between Health issues and the duration of conducting online classes for the students.

H1: There is a significant relationship between Health issues and the duration of conducting online classes for the students.

Cross Tabulation between Health Issues and Duration of Online Classes of the Students

\begin{tabular}{|c|c|c|c|c|c|c|}
\hline \multirow{2}{*}{\multicolumn{2}{|c|}{ Particulars }} & \multicolumn{4}{|c|}{ Number of Hours Conducts Online Classes Per Day } & \multirow{3}{*}{$\begin{array}{c}\text { Total } \\
83\end{array}$} \\
\hline & & \multirow{2}{*}{\begin{tabular}{|c|} 
One Hour \\
13 \\
\end{tabular}} & \multirow{2}{*}{$\begin{array}{c}\text { Two Hours } \\
0\end{array}$} & \multirow{2}{*}{$\begin{array}{c}\text { Three Hours } \\
62 \\
\end{array}$} & \multirow{2}{*}{$\begin{array}{c}\text { More Than Three Hours } \\
8\end{array}$} & \\
\hline \multirow{2}{*}{ Facing Health Issues } & Yes & & & & & \\
\hline & No & 15 & 2 & 20 & 0 & 37 \\
\hline \multicolumn{2}{|l|}{ Total } & 28 & 2 & 82 & 8 & 120 \\
\hline
\end{tabular}

Source: Computed data

Chi - Square Test Computed Values

\begin{tabular}{|l|c|c|c|}
\hline \multicolumn{1}{|c|}{ Particulars } & Value & Df & $\begin{array}{c}\text { Asymp. Sig. } \\
\text { (2-Sided) }\end{array}$ \\
\hline Pearson Chi-Square & 137.574 A & 8 & 0.000 \\
\hline Likelihood Ratio & 30.065 & 8 & 0.000 \\
\hline N. Of Valid Cases & 120 & \multicolumn{2}{|c|}{} \\
\hline
\end{tabular}

Source: Computed data

The above table, shows usage of more hours in Electronic gadgets causes health issues of the students. Under chi-square test calculation, a significant value $(0.05)$ is greater than the calculated value $(0.000)$. Therefore, there is a significant relationship between health issues and the duration of online classes for the students. So, the null hypothesis is rejected.

\section{t-Test}

\section{Paired Sample t-Test}

H0: There is no significant relationship between usage of data and platform using in online classes

H1: There is significant relationship between usage of data and platform using in online classes

\section{Paired Sample Statistics}

\begin{tabular}{|l|c|c|c|c|}
\hline \multicolumn{1}{|c|}{ Variables } & Mean & $\mathbf{N}$ & $\begin{array}{c}\text { Std. } \\
\text { Deviation }\end{array}$ & $\begin{array}{c}\text { Std. } \\
\text { Error } \\
\text { Mean }\end{array}$ \\
\hline $\begin{array}{l}\text { Usage of Data in } \\
\text { Online Class }\end{array}$ & 1.64 & 120 & 0.658 & 0.060 \\
\hline $\begin{array}{l}\text { Plat Form Using } \\
\text { for Online Classes }\end{array}$ & 1.78 & 120 & 0.522 & 0.048 \\
\hline
\end{tabular}

Paired Samples Correlations

\begin{tabular}{|c|c|c|c|}
\hline Variable & $\mathbf{N}$ & Correlation & Sig. \\
\hline $\begin{array}{l}\text { Use Age of Data } \\
\text { in Online Class \& } \\
\text { Platform Using for } \\
\text { Online Classes }\end{array}$ & 120 & 0.237 & 0.009 \\
\hline
\end{tabular}




\begin{tabular}{|c|c|c|c|c|c|c|c|c|}
\hline \multicolumn{9}{|c|}{ Paired Sample t-Test } \\
\hline \multirow{3}{*}{ Particulars } & \multicolumn{8}{|c|}{ Paired Differences } \\
\hline & \multirow[t]{2}{*}{ Mean } & \multirow{2}{*}{$\begin{array}{c}\text { Std. } \\
\text { Deviation }\end{array}$} & \multirow{2}{*}{$\begin{array}{l}\text { Std. } \\
\text { Error } \\
\text { Mean }\end{array}$} & \multicolumn{2}{|c|}{$\begin{array}{l}95 \% \text { Confidence Interval } \\
\text { of the Difference }\end{array}$} & \multirow[t]{2}{*}{ t-Value } & \multirow[t]{2}{*}{ Df } & \multirow{2}{*}{$\begin{array}{l}\text { Sig. } \\
\text { (2-Tailed) }\end{array}$} \\
\hline & & & & Lower & Upper & & & \\
\hline $\begin{array}{l}\text { Usage of Data in Online } \\
\text { Class Platform Using for } \\
\text { Online Classes }\end{array}$ & 0.142 & 0.737 & 0.067 & 0.275 & 0.008 & 2.106 & 119 & 0.037 \\
\hline
\end{tabular}

Source: Computed data

The above shows that usage of data in online classes and the platform using for online classes were positively correlated at $0.237, \mathrm{P}<0.0001)$. The significant value $(0.05)$ is greater than the calculated value 0.037 . There is significant relationship between data usage in online classes and the platform using for online classes. So null hypothesis is rejected.

\section{ANOVA}

H0: There is no significant relationship between Teaching methods and the Satisfaction level of students in online classes.

H1: There is a significant relationship between Teaching methods and the Satisfaction level of students in online classes.

\begin{tabular}{|c|c|c|c|c|c|c|}
\hline \multicolumn{7}{|c|}{ ANOVA } \\
\hline Factors & Anova & $\begin{array}{l}\text { Sum of } \\
\text { Squares }\end{array}$ & Df & Mean Square & $\mathbf{F}$ & Sig. \\
\hline \multirow{3}{*}{$\begin{array}{l}\text { Delivery of content are } \\
\text { understandable (F1) }\end{array}$} & Between Groups & 21.970 & 1 & 21.970 & \multirow{2}{*}{14.579} & \multirow{2}{*}{0.000} \\
\hline & Within Groups & 177.822 & 118 & 1.507 & & \\
\hline & Total & 199.792 & 119 & & & \\
\hline \multirow{3}{*}{$\begin{array}{l}\text { Interaction between } \\
\text { teachers and student in } \\
\text { online classes (F2) }\end{array}$} & Between Groups & 17.131 & 1 & 17.131 & \multirow{2}{*}{7.673} & \multirow{2}{*}{0.007} \\
\hline & Within Groups & 263.461 & 118 & 2.233 & & \\
\hline & Total & 280.592 & 119 & & & \\
\hline \multirow{3}{*}{$\begin{array}{l}\text { Problem papers are easy } \\
\text { to understand (F3) }\end{array}$} & Between Groups & 30.599 & 1 & 30.599 & \multirow{2}{*}{22.007} & \multirow{2}{*}{0.000} \\
\hline & Within Groups & 164.068 & 118 & 1.390 & & \\
\hline & Total & 194.667 & 119 & & & \\
\hline \multirow{3}{*}{$\begin{array}{l}\text { I satisfied with assessment } \\
\text { and activity (F4) }\end{array}$} & Between Groups & 15.839 & 1 & 15.839 & \multirow{2}{*}{12.849} & \multirow{2}{*}{0.000} \\
\hline & Within Groups & 145.461 & 118 & 1.233 & & \\
\hline & Total & 161.300 & 119 & & & \\
\hline \multirow{3}{*}{$\begin{array}{l}\text { Time management is } \\
\text { effective in online classes } \\
\text { (F5) }\end{array}$} & Between Groups & 10.456 & 1 & 10.456 & \multirow{2}{*}{7.037} & \multirow{2}{*}{0.009} \\
\hline & Within Groups & 173.863 & 117 & 1.486 & & \\
\hline & Total & 184.319 & 118 & & & \\
\hline
\end{tabular}

Source: Computed data

- The above table shows that using teaching methods and the satisfaction level of the students towards online classes, the level of satisfaction was tested in each Factor.

- The P value of a F1 - 0.000, F3 - 0.000, F4 - 0.000 is less than the significance value (0.01).

- Therefore there is a significant relationship between teaching methods and the satisfaction level of students regarding the delivery of the content understanding level of problem papers,
Assessment and activity in online classes. so, the null hypothesis is rejected

- The P value of a F2 - 0.007, F5 - 0.009 is more than the significant value $(0.05)$.

- There is no relationship between teaching methods and satisfaction level of interaction between students and teachers in online classes, Satisfaction regarding effectiveness in time management, so the null hypothesis is accepted. 


\section{Suggestions}

- Students study five to six subjects in a semester through e-learning; time management was a major constraint for them to complete the academic work to look over it.

- Even though virtual learning helps them to improve their knowledge but they face some health issues, so parents and the faculty must take responsibility.

- Lockdown period must utilize properly; using the smart phone by all the time is need to monitor by the parents who are more responsible.

- The major drawback in e-learning is not able to identify the reaction of the students, so other then the academic mode of teaching faculties can arrange for meeting to share the views of students related to e-learning, since it is new for both the side.

\section{Conclusion}

Learning through virtual mode during this lockdown period is much useful for the students but they prefer to be attending the classes on campus, where they can get better touch with the faculties and friends of them. Much interested in learning new things through e-learning but because of network issue, data card problems, power cut issues both students and faculties are much affected.

\section{References}

Abbasi, Sahar, et al. "Perceptions of Students regarding E-learning during Covid-19 at a Private Medical College." Pakistan Journal of Medical Sciences, vol. 36, 2020.

Adewole-Odeshi, Egbe. "Attitude of Students Towards E-learning in South-West Nigerian Universities: An Application of Technology Acceptance Model." Library Philosophy and Practice, 2014.

Adnan, Muhammad, and Kainat Anwar. "Online Learning amid the COVID-19 Pandemic:
Students' Perspectives." Journal of

Pedagogical Sociology and Psychology, vol. 2, no. 1, 2020.

Ali, Naila, et al. "Attitude of Nursing Students towards E-Learning." Advances in Health Professions Education, vol. 2, no. 1, 2016.

Bernard, Robert M., et al. "The Development of a Questionnaire for Predicting Online Learning Achievement." Distance Education, vol. 25, no. 1, 2004, pp. 31-47.

Dhamija, Neelam. "Attitude of Undergraduate Students Towards the use of e-Learning." MIER Journal of Educational Studies, Trends and Practices, vol. 4, 2016, pp. 123-135.

Kisanga, Dalton H. "Determinants of Teachers' Attitudes towards E-Learning in Tanzanian Higher Learning Institutions." International Review of Research in Open and Distributed Learning, vol. 17, no. 5, 2016, pp. 109-125.

Margaret Divya, A., and Suganthi Priya. "A Study on the Impact of Covid-19 on Students Learning Experiences with Special Reference to Madurai City." ComFin Research, vol. 9, no. 1, 2021, pp. 11-16.

Peytcheva-Forsyth, Roumiana. "Factors Affecting Students' Attitudes Towards Online Learning - The Case of Sofia University." AIP Conference Proceedings, 2018.

Saravanakumar, AR., et al. "Educational Technological Vision on Distance Mode (DM) in Teacher Education Programme (TEP)." Global Web Conference on Multidisciplinary Research and Development, 2020.

Ullah, Obaid. "Students' Attitude towards Online Learning at Tertiary Level." PUTAJ Humanities and Social Sciences, vol. 25, no. 1-2, 2017, pp. 63-82.

Zhu, Yue. "University Students' Attitudes toward Online Learning in a Blended Course." AARE Annual Conference, 2013.

\section{Author Details}

Mrs. M. Parimala, Associate Professor, Department of Commerce, Lady Doak College, Madurai, Tamil Nadu, India

Ms. V. Gayathri, Assistant Professor, Department of Commerce, Mangayarkarasi College of Arts and Science for Women, Madurai, Tamil Nadu, India, Email ID: gayathrivelu135@gmail.com 


\title{
GST Repercussion on Financial Reporting under IND AS Regime
}

\author{
Heena Tabasum \\ Research Scholar, Department of PG Studies and Research in Commerce \\ Kvempu University, Shimoga District, Karnataka, India \\ (D) https://orcid.org/0000-0003-1564-061X
}

\section{OPEN ACCESS}

Manuscript ID:

COM-2021-09023660

Volume: 9

Issue: 2

Month: April

Year: 2021

E-ISSN: 2582-6190

Received: 28.01.2021

Accepted: 09.03.2021

Published: 01.04.2021

Citation:

Tabasum, Heena, and

S. Venkatesh. "GST

Repercussion on Financial

Reporting under IND

AS Regime." ComFin

Research, vol. 9, no. 2, 2021, pp. 9-13.

DOI:

https://doi.org/10.34293/

commerce.v9i2.3660

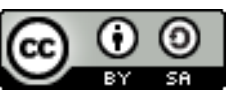

This work is licensed under a Creative Commons Attribution-ShareAlike 4.0 International License

\section{S. Venkatesh}

Professor and Chairman, Department of PG Studies and Research in Commerce Kvempu University, Shimoga District, Karnataka, India

\section{Abstract}

Indian economy witnessed the biggest reform ever seen since independence is the GST introduction and application of accounting standards converged with Global standards, namely, IND AS. Both GST and IND ASare scorching topics of the period, as taxing goods or services and accounting can be seen as dependent on each other as they go in tandem with each other. Changes can be witnessed in the field of business, finance, accounting and reporting due to the GST move in India along with changes in tax command. Financial information is the primary source of information to the users to know about the performance of the company, which is prepared by considering the guidelines of IND AS and the transaction value is determined by considering GST law. This paper intends to bring light to the area of impact of GST on reporting of financial performance under the IND AS regime by considering GST aspects like an input tax credit, revenue recognition, events treatment etc.., for this purpose, both primary and secondary data has been used. Analysis is done by using some statistical tools, test, graphs, and tables. With GST introduction, every business has changed and do with accounting practices; an attempt has been made to trace such changes and their impact.

Keywords: GST, IND AS, ITC, Disclosure, Revenue Recognition, Financial reporting, PPE

\section{Introduction}

Financial reports are demanded by the investors, who are the prime virtue for getting information about its performance, financial position, and profitability. The corporates have to report their performance to both internal and external parties by following the guidelines of Indian Accounting Standards, which are converged with IFRS. Financial reports in our country should be prepared by considering IND AS, which has been significantly changed due to the introduction of GST, as it is a destination-based tax system that bring a paradigm shift in the old indirect tax regime by subsuming most of the indirect taxes. Financial Reporting is the movement of information from the private domain to the public domain. The information communicated to the external parties should be in a proper manner. Such a tool for communicating financial information is the financial statements; such financial statements need to be prepared by considering and following guidelines under Indian Accounting Standards, popularly known as IND AS. Due to enforcement of GST law in the Indian economy, its repercussion can be seen in accounting backed by IND AS. 


\section{Concepts}

1. GST: It is an indirect tax that subsumed most of the indirect taxes in India and levied on the supply of goods or services or both. It is a destinationbased value-added tax levied by the Govt. of India on all the stages of the production process, which is meant for a refund for all the parties involved in the stages of production except to the final consumer. The burden of the tax finally falls to the ultimate consumers.

2. IND AS: Indian Accounting Standards, abbreviated as IND AS, is the accounting standards adopted by the Companies in India issued under the supervision of the Accounting Standard Board. IND AS are the rules according to which accounting statements have to be prepared. They demand minimum levels of disclosure, establish fundamental principles, delineate the meanings of terms, and stipulate how numbers must be calculated.

3. Financial Reporting: Financial Reporting refers to the system of preparing and submitting the financial reports disclosing their financial position and performance with necessary details, notes, statements, and other information to different stakeholders.

\section{Need for Study}

Transition to GST in India brings not only changes in tax structure but certainly on complete business, finance, accounting, and reporting. Accounting is a language of business that communicates financial information, performance and position of a company to its stakeholders and shareholders, either existing or prospective. Such information is a tool to make financial and investment decisions. Financial reporting, which includes the financial statements, needs to be prepared as per IND AS, which are converged with IFRS to facilitate uniformity, transparency, comparison and meeting global standard requirements. With the primer of GST, the implication of it is not only restricted to taxation. Its implication goes beyond taxation and it fundamentally impacts various aspects of finance, accounting, and reporting and such changes have to be analyzed carefully.

\section{Objectives of the Study}

1. To understand the interplay of GST with IND AS accounting.

2. To highlight the repercussion of GST on IND AS financial reporting.

3. To analyze the perception of accountants towards GST implication on IND AS financial accounting.

4. To offer suggestions based on the findings of the study.

\section{Study Hypothesis}

H0: There is no significant impact of GST on IND AS Financial reporting

H1: There is a significant impact of GST on IND AS Financial and reporting

\section{Research Methodology}

Data Source: The present study is based on the information which is collected by both the type of data such as, Primary data which is collected by distributing a questionnaire to the respondents and by conducting a personal interview. Secondary data is collected from reviewing various articles, newspapers, magazines, books and different websites.

Sampling: For the purpose of achieving the objectives, the present study undertook a sample of 50 respondents, who are the accountants working in selected companies of Bangalore and a convenient sampling technique has been used.

Statistical Tools and Techniques: For the purpose of analyzing the data collected from various sources, certain statistical tools and techniques have been used, such as tables, percentages and Chi-square test. Results and Discussions: The data from the sources have been analysed and the major findings from the analysis are discussed as below. Hypothesis Testing the Chi-square test has been used to test the formulated hypothesis.

Table 1: Impact of GST on IND AS Financial Reporting

\begin{tabular}{|c|c|c|c|c|}
\hline Particulars & $\begin{array}{c}\text { Observed } \\
(\mathbf{0})\end{array}$ & $\begin{array}{c}\text { Expected } \\
(\mathbf{E})\end{array}$ & O-E & (O-E) $^{\mathbf{2}}$ \\
\hline Yes & 45 & 37 & 08 & 64 \\
\hline No & 05 & 13 & -08 & 64 \\
\hline
\end{tabular}

